\title{
The Role of Investment and Innovation Activities of Coal Mining Enterprises in Increasing the Level of Environmental Safety of Country and Region
}

\author{
Oksana Sheveleva ${ }^{1, *}$, Ekaterina Slesarenko ${ }^{1}$, Natalia Kudrevatykh $^{1}$, and Maria \\ Kumaneeva $^{1}$ \\ ${ }^{1}$ T.F. Gorbachev Kuzbass State Technical University, Department of Finance and Credit, 650000 \\ Kemerovo, 28 Vesennya st., Russian Federation
}

\begin{abstract}
The key role of investment and innovation activities of coal industry enterprises in improving the environmental safety of regions specializing in coal mining is substantiated in the article. The coal industry enterprises are recognized by the world scientific community as the absolute leader in the field of negative impact on the environment and industrial production waste generation. In this regard, one of the most important tasks of increasing the investment and innovation activities of coal companies, the introduction of modern technologies should be not only an increase in labor productivity and production efficiency, but also a reduction of anthropogenic impact on the environment. Despite the obviousness of the presented thesis, the trends characterizing the coal industry as the most inert and low-innovative sphere, which follows the path of extensive development, continue to dominate. The insignificant increase in investments in fixed assets, periodically followed by a recession, the reduction of trapped and neutralized air polluting substances, the lack of demand for innovations in the coal industry, as well as their low impact on ensuring compliance with modern technical standards, procedures and rules, bear evidence of low responsibility of business entities and inefficient measures of state economic policy in the field of improving environmental safety in the commodity-dependent regions.
\end{abstract}

\section{Introduction}

Human activities constantly cause environmental damage, namely:

- air pollution as a result of the generation of significant greenhouse gas volumes, contributing to changes in climatic conditions, as well as increasing the content of harmful and dangerous substances in the atmosphere, causing an increase in the incidence of the population;

- the destruction of forests, which are the "lungs" of the planet and the habitat of many species of wild animals;

\footnotetext{
* Corresponding author: shob.fk@kuzstu.ru
} 
- the deterioration of soil qualities, including those previously fertile;

- the pollution of water bodies, and, as a result, the reduction of river and marine biological resource base;

- increasing radiation load and environmental degradation in general as a result of vigorous industrial activity, which is often not accompanied by adequate environmental measures.

The role of commodity-dependent regions in forming a significant environmental burden in countries of their operation is traditionally high, which is due to both the nature of the industry's activity, often accompanied by "predatory" methods of mining using outdated technologies, and the desire of owners and management to save on environmental and nature restoration activities. Even those extractive industry companies that try to be environmentally responsible doing their business, cause significant damage to the environment due to the industry specifics. This is especially true for coal mining enterprises, as they can simultaneously have a negative impact on various natural objects (water, air, forest, soil, etc.).

\section{Materials and Methods}

The introduction of new modern technologies in industrial enterprises often allows not only to increase labor productivity and the efficiency of using various resources (material, labor, financial), but also to reduce the degree of harmful effects on the environment. The interconnection of engineering, technological and environmental components of the development of commodity-dependent regions is emphasized in the works of numerous scientists [1-4]; it has been also studied in detail in our work [5].

In this regard, the investment activity of extractive industry enterprises, and, first of all, coal mining enterprises, in the reconstruction and modernization of fixed assets, is extremely important, both from the point of view of improving the engineering and technological characteristics of these facilities, and from the point of view of reducing the level of harmful effects on the state of the environment, the expansion of innovation activity of enterprises in order to ensure compliance of the engineering, technological and environmental components of the production activity with modern new regulations and standards.

An analysis of Russian statistics showed that the share of investments in reconstruction and modernization in the total volume of investments in fixed assets in the coal mining was the largest among the extractive industry sectors, amounting to $19.0 \%$ in $2017,19.2 \%$ in 2018 (Table 1). Moreover, it exceeded the share of investments in all types of economic activity in the Russian Federation in aggregate, namely: $16.1 \%$ and $15.5 \%$. And the share of investments in machinery and equipment in investments in fixed assets related to modernization and reconstruction in the coal mining was at least two times higher than in other sectors of the extractive industry.

At the same time, there has been a significant increase in investment in fixed assets aimed at modernization and reconstruction in the coal mining - 122.2\% compared to last year. In the extractive industry, an excess of this indicator was achieved only in the industry related to the metal ore mining (growth rate is $154.6 \%$ ). The average increase in investment in the reconstruction and modernization of fixed assets of economic activity types in Russia amounted to $1.6 \%$.

For 2017-2018, the commissioning of fixed assets increased from 89.5 kopecks to 91.5 kopecks per 1 ruble of investments, that is, by $2.2 \%$. However, along with this, a number of negative trends are also observed: an increase in the level of depreciation of fixed assets by $1.4 \%$, a decrease in their renewal coefficient by $1.1 \%$ and a decrease in the index of change in capital-labor ratio by $1.4 \%$. 
Table 1. Dynamics of indicators of investment activity of extractive industry in the field of reconstruction and modernization.

\begin{tabular}{|c|c|c|}
\hline Extractive industry sector & 2017 & 2018 \\
\hline \multicolumn{3}{|c|}{$\begin{array}{c}\text { The share of investments aimed at modernization and reconstruction } \\
\text { in the total amount of investment in fixed assets, } \%\end{array}$} \\
\hline Coal mining & 19.0 & 19,2 \\
\hline \multicolumn{3}{|l|}{ For comparison: } \\
\hline - natural gas and oil production & 10.2 & 7,1 \\
\hline - metal ore mining & 7.9 & 10,2 \\
\hline - extraction of other minerals & 4.5 & 4,8 \\
\hline \multicolumn{3}{|c|}{$\begin{array}{l}\text { The share of investments in machinery and equipment in investments } \\
\text { in fixed assets allocated for reconstruction and modernization, } \%\end{array}$} \\
\hline Coal mining & 86.8 & 69,7 \\
\hline \multicolumn{3}{|l|}{ For comparison: } \\
\hline - natural gas and oil production & 6.4 & 7,6 \\
\hline - metal ore mining & 41.7 & 33,4 \\
\hline - extraction of other minerals & 41.7 & 32,7 \\
\hline \multicolumn{3}{|c|}{$\begin{array}{l}\text { Index of investments in fixed assets allocated for modernization and } \\
\text { reconstruction, } \\
\text { as a percentage of the rate of } 2017\end{array}$} \\
\hline Coal mining & & 122.2 \\
\hline \multicolumn{3}{|l|}{ For comparison: } \\
\hline - natural gas and oil production & & 68.9 \\
\hline - metal ore mining & & 154.6 \\
\hline - extraction of other minerals & & 80.2 \\
\hline $\begin{array}{l}\text { All studied types of economic activity } \mathrm{i} \\
\text { Federation }\end{array}$ & e Russian & 101.6 \\
\hline
\end{tabular}

In 2018, compared with the level of 2017, there was a significant decrease in investment in fixed assets in the extractive industry aimed at environmental protection - by 10912.1 million rubles or $23.1 \%$ (Table. 2). This is due to a reduction in the amount of investments in all environmental activities - with a predominant decrease in air protection. The opposite trend is observed for investments in coal mining - an increase of 505.5 million rubles or $28.9 \%$ due to growth in all areas, excluding the costs of waste management.

The maximum share of investments in the extractive industry is in air protection $(58 \%$ in 2017 and $56 \%$ in 2018), in the field of coal mining - in the protection of water resources (97\% and 83\%, respectively, in 2017-2018).

Considering the share of investments in coal mining enterprises in the total amount of investments in the extractive industry, its extremely low indicators can be noted: $3.7 \%$ in 2017 and $6.2 \%$ in 2018.

Table 2. Dynamics of investments in fixed assets in the field of environmental protection, million rubles.

\begin{tabular}{|l|c|c|c|c|}
\hline \multirow{2}{*}{\multicolumn{1}{|c|}{ Environmental activities }} & \multicolumn{2}{|c|}{$\mathbf{2 0 1 7}$} & \multicolumn{2}{c|}{$\mathbf{2 0 1 8}$} \\
\cline { 2 - 5 } & $\begin{array}{c}\text { extractive } \\
\text { industry }\end{array}$ & $\begin{array}{c}\text { coal } \\
\text { mining }\end{array}$ & $\begin{array}{c}\text { extractive } \\
\text { industry }\end{array}$ & $\begin{array}{c}\text { coal } \\
\text { mining }\end{array}$ \\
\hline Total investment, & 47330.1 & 1746.7 & 36418.0 & 2252.2 \\
\hline including: & & & & \\
\hline - air protection & 27227.4 & 13.1 & 20288.1 & 132.6 \\
\hline - water resources protection & 9712.6 & 1688.4 & 7998.3 & 1872.3 \\
\hline $\begin{array}{l}\text { - environmental protection from the } \\
\text { effects of production and }\end{array}$ & 5705.8 & 18.3 & 3566.8 & 6.8 \\
\hline
\end{tabular}




\begin{tabular}{|l|l|l|l|l|}
\hline consumption waste & & & & \\
\hline - land reclamation & 2498.8 & 22.0 & 2312.4 & 31.5 \\
\hline
\end{tabular}

Along with investment infusions, the extractive industry actively bears current environmental costs (Table 3). The total amount of such costs in 2018 in the Russian Federation amounted to about 346 billion rubles, of which the share of the extractive industry was $15 \%$.

The maximum current costs in 2018 were born in the following areas of environmental protection:

1. Wastewater collection and treatment:

- extractive industry $-33 \%$ of the total current costs;

- coal mining $-48.5 \%$ of the total cost;

2. Waste management:

- extractive industry $-25.7 \%$ of the total current costs;

- coal mining $-16.2 \%$ of the total cost;

3. Air protection:

- extractive industry $-22.5 \%$ of the total current costs;

- coal mining $-26.1 \%$ of the total cost.

The total current costs in the extractive industry increased in $2017-2018$ by 2,783 million rubles or by $5.5 \%$. The growth was noted in all environmental activities, with the exception of air protection.

In the field of coal mining, on the contrary, there was a decrease in the level of current costs - by 63.6 million rubles or $3.4 \%$, which was due to cost reduction in almost all environmental activities, except for the cost item "Waste Management" (an increase of 49.1 million rubles or $22.4 \%$ ). The maximum decrease in current environmental protection costs in absolute terms is observed in the air protection activities (by 68.8 million rubles).

Studying the share of current costs at coal mining enterprises in the total amount of costs in the extractive industry, we can note its extremely low rates: $3.4 \%$ in 2017 and $3.1 \%$ in 2018 .

Table 3. Dynamics of current costs for each environmental activity, million rubles.

\begin{tabular}{|l|c|c|c|c|}
\hline \multirow{2}{*}{ Activities } & \multicolumn{2}{|c|}{$\mathbf{2 0 1 7}$} & \multicolumn{2}{c|}{$\mathbf{2 0 1 8}$} \\
\cline { 2 - 5 } & $\begin{array}{c}\text { extractive } \\
\text { industry }\end{array}$ & $\begin{array}{c}\text { coal } \\
\text { mining }\end{array}$ & $\begin{array}{c}\text { extractive } \\
\text { industry }\end{array}$ & $\begin{array}{c}\text { coal } \\
\text { mining }\end{array}$ \\
\hline Total & 50217 & 1721 & 53000 & 1657 \\
\hline - air protection & 12225 & 502 & 11951 & 433 \\
\hline - waste water treatment & 17085 & 838 & 17502 & 804 \\
\hline - waste management & 11251 & 219 & 13631 & 268 \\
\hline $\begin{array}{l}\text { - land, groundwater and } \\
\text { surface water protection }\end{array}$ & 8241 & 131 & 8626 & 106 \\
\hline - other areas & 1415 & 31 & 1291 & 45 \\
\hline
\end{tabular}

The costs of overhaul of fixed assets related to environmental protection were also significant (Table 4). The total amount of such costs in 2018 was 22 billion rubles, including 3.3 billion rubles accounted for the extractive industry (14.9\% of the total cost of all activities).

Among the leading areas in the costs of overhaul of fixed assets related to environmental protection in the extractive industry, the following areas of environmental protection can be distinguished:

- protection and reclamation of land, surface and groundwater $-37.7 \%$ of the total cost; 
- waste management $-34.8 \%$ of the total cost;

- collection and treatment of waste water $-20.3 \%$ of the total cost.

As for coal mining, in 2018 the total amount of the costs of overhaul of fixed assets related to environmental protection amounted to 23.9 million rubles, of which $75.7 \%$ was spent on wastewater collection and treatment, and the rest to air protection. The share of coal mining enterprises in the total costs of the extractive industry industry was minimal, amounting to only $0.7 \%$.

Table 4. The costs of overhaul of fixed assets related to environmental protection, million rubles.

\begin{tabular}{|l|c|c|c|}
\hline $\begin{array}{c}\text { Environmental } \\
\text { activities }\end{array}$ & Total & $\begin{array}{c}\text { Extractive } \\
\text { industry }\end{array}$ & $\begin{array}{c}\text { Coal } \\
\text { mining }\end{array}$ \\
\hline Total & 22106 & 3286 & 24 \\
\hline - air protection & 5964 & 233 & 6 \\
\hline $\begin{array}{l}\text { - waste water } \\
\text { treatment }\end{array}$ & 10938 & 669 & 18 \\
\hline $\begin{array}{l}\text { - waste } \\
\text { management }\end{array}$ & 2775 & 1142 & - \\
\hline $\begin{array}{l}\text { - land, } \\
\text { groundwater and } \\
\text { surface water } \\
\text { protection }\end{array}$ & 2166 & 1240 & - \\
\hline - other areas & 263 & 2 & - \\
\hline
\end{tabular}

The innovation activity of entities is one of the important indicators for assessing the level of their engineering and technological advancement (Table 5). Analyzing the dynamics of the cost of innovative goods, works, services, it can be noted that their total amount in various activities for the period 2012-2018 in the Russian Federation increased by 999.2 billion rubles or almost $50 \%$, while a decrease of 122.7 billion rubles or $8.9 \%$ is observed in the extractive industry. As a result, the share of the extractive industry in the country's total production activity for seven years decreased by $9.9 \%$; however, since 2014 , this indicator has begun to grow.

The number of new technologies acquired by companies is decreasing both in general in production activities in the Russian Federation and in the extractive industry. However, in the extractive industry, this decline is proceeding more rapidly $(54.1 \%$ versus $71.7 \%)$, as a result of which the share of the extractive industry in production activities decreased by $0.3 \%$ over seven years.

The opposite dynamics of indicators in production activity in general and in the extractive industry is also observed in the indicator "Level of innovation activity of companies": in 2012-2018, an increase of $2.5 \%$ for general industry activity in the country, and a decrease of $0.3 \%$ in extractive industry were noted.

From the perspective of evaluating the innovation activity of enterprises, it is interesting to analyze the dynamics of the indicator, which reflects the degree of influence of the results of the introduction of innovations on ensuring compliance with modern technical regulations and standards. So, in 2018, in various types of economic activity of the country, $40 \%$ of innovations did not have any effect on ensuring compliance with technical regulations and standards, another $10.8 \%$ of innovations showed a low level of influence, and $24.2 \%$ - an average level. And only $24.9 \%$ of innovations had a significant impact.

For primary industries, the situation looks even more depressing:

- the introduction of $56 \%$ of innovations did not contribute to the achievement of compliance of production conditions with modern regulations and standards;

$-8.7 \%$ had a low impact; 
$-15.3 \%$ had an average impact;

- and only $20 \%$ had a high impact.

In addition, the situation is only getting worse in dynamics. So, for example, in 2012, only $32.2 \%$ of innovations did not affect the indicator in question (which is $23.8 \%$ lower than in 2018), and a significant positive effect was observed for $56.4 \%$ of innovations.

Table 5. Dynamics of indicators of innovation activity of the extractive industry companies.

\begin{tabular}{|c|c|c|c|c|c|c|c|}
\hline \multirow{2}{*}{ Indicators } & \multicolumn{7}{|c|}{ year } \\
\hline & 2012 & 2013 & 2014 & 2015 & 2016 & 2017 & 2018 \\
\hline \multicolumn{8}{|c|}{$\begin{array}{c}\text { a. Innovative goods and services introduced for the first time or significantly } \\
\text { improved over the past three years }\end{array}$} \\
\hline $\begin{array}{l}\text { Total, billion } \\
\text { rubles }\end{array}$ & 2007 & 24167 & 1931 & 2639 & 3211 & 3014 & 3007 \\
\hline $\begin{array}{l}\text { Extractive } \\
\text { industry, } \\
\text { billion rubles }\end{array}$ & 354 & 353 & 45 & 153 & 202 & 225 & 232 \\
\hline $\begin{array}{l}\text { The share of } \\
\text { the extractive } \\
\text { industry in } \\
\text { industrial } \\
\text { activity as a } \\
\text { whole, \% }\end{array}$ & 17.6 & 14.6 & 2.3 & 5.8 & 6.3 & 7.5 & 7.7 \\
\hline \multicolumn{8}{|c|}{ b. The number of new technologies and software acquired by organizations } \\
\hline Total, items & $\begin{array}{c}31 \\
639 \\
\end{array}$ & $\begin{array}{c}33 \\
280\end{array}$ & $\begin{array}{c}28 \\
705\end{array}$ & $\begin{array}{c}24 \\
361\end{array}$ & $\begin{array}{c}64 \\
914 \\
\end{array}$ & $\begin{array}{c}20 \\
042\end{array}$ & $\begin{array}{c}22 \\
678 \\
\end{array}$ \\
\hline $\begin{array}{l}\text { Extractive } \\
\text { industry, } \\
\text { items }\end{array}$ & 484 & 428 & 338 & 266 & 400 & 361 & 262 \\
\hline $\begin{array}{l}\text { The share of } \\
\text { the extractive } \\
\text { industry in } \\
\text { industrial } \\
\text { activity as a } \\
\text { whole, \% }\end{array}$ & 1.5 & 1.3 & 1.2 & 1.1 & 0.6 & 1.8 & 1.2 \\
\hline \multicolumn{8}{|c|}{ c. The level of innovation activity of companies } \\
\hline Total, \% & 10.3 & 10.1 & 9.9 & 9.3 & 8.4 & 14.6 & 12.8 \\
\hline $\begin{array}{l}\text { Extractive } \\
\text { industry, \% }\end{array}$ & 8.2 & 7.6 & 7.5 & 6.9 & 7.4 & 8.9 & 7.9 \\
\hline \multicolumn{8}{|c|}{$\begin{array}{l}\text { d. The level of influence of the results of the introduction of innovations on } \\
\text { ensuring compliance with modern technical standards and regulations }\end{array}$} \\
\hline Total, items & & & & & & & \\
\hline - low impact & 587 & 591 & 541 & 568 & 518 & 532 & 567 \\
\hline $\begin{array}{l}\text { - average } \\
\text { impact }\end{array}$ & 1538 & 1550 & 1506 & 1481 & 1370 & 1277 & 1268 \\
\hline $\begin{array}{l}\text { - high } \\
\text { impact }\end{array}$ & 1553 & 1594 & 1715 & 1768 & 1487 & 1245 & 1308 \\
\hline - no impact & 1057 & 1094 & 1045 & 1010 & 1739 & 1872 & 2101 \\
\hline $\begin{array}{l}\text { Extractive } \\
\text { industry, } \\
\text { items }\end{array}$ & & & & & & & \\
\hline - low impact & 17 & 20 & 16 & 15 & 12 & 11 & 13 \\
\hline $\begin{array}{l}\text { - average } \\
\text { impact }\end{array}$ & 49 & 40 & 40 & 41 & 35 & 32 & 23 \\
\hline $\begin{array}{l}\text { - high } \\
\text { impact }\end{array}$ & 35 & 32 & 36 & 44 & 39 & 30 & 30 \\
\hline - no impact & 48 & 45 & 43 & 36 & 48 & 60 & 84 \\
\hline
\end{tabular}


An analysis of the dynamics of environmental indicators in the Russian Federation reflects an increase in production and consumption waste in the extractive industry in 20172018 by 1064.3 million tons or $18.4 \%$, and in the coal mining - by 942 million tons or by $24.3 \%$. As a result, the share of production and consumption waste related with the activities of coal mining enterprises in the extractive industry as a whole increased from $67 \%$ to $70.3 \%$. And the share of production and consumption waste in the extractive industry in the country's industrial production as a whole in 2018 amounted to $96.2 \%$, which characterizes the extractive industry as an absolute leader in the generation of industrial production waste. A similar conclusion is shared by a number of Russian and foreign scientists [6-12].

At the same time, there is a reduction in emissions of air polluting substances from stationary sources and discharge of polluted wastewater. However, along with a decrease in atmospheric emissions, there is a decrease in trapped and neutralized air pollutants, and it is happening at a faster pace. Thus, the positive dynamics of reducing air polluting substances is offset by a decrease in the share of trapped and neutralized substances.

\section{Results and Discussion}

According to the results of the study, we can highlight the following positive aspects in the investment and innovation activities of coal mining enterprises of the Russian Federation:

1. The share of investments aimed at modernization and reconstruction in the coal mining in 2017-2018 was the highest among all sectors of the extractive industry in Russia, and significantly exceeded the share of investments in all types of economic activity in general.

2. There is a significant increase in investment in fixed assets aimed at modernization and reconstruction in the coal mining, as well as an increase in fixed assets per 1 ruble of investments.

3. A significant increase in the amount of investments in fixed assets for environmental protection was noted.

Along with this, during the analysis, a number of significant problems were noted, which is also confirmed by the studies presented in [13-15]:

1. An increase in the depreciation of fixed assets, a decrease in their renewal coefficient and a decrease in the index of change in capital-labor ratio.

2. Reducing the level of current costs in all environmental protection activities with the maximum reduction in the area of air protection.

3. Extremely low values of the indicators "The share of investments in fixed assets for environmental protection in the coal mining in the total volume of investments in the extractive industry" and "The share of current environmental protection costs in the coal mining in the total costs of the extractive industry".

4. The minimum share of costs for the overhaul of fixed assets related to environmental protection in the coal mining (less than $1 \%$ of the total amount of such costs in the extractive industry in 2018).

5. The low degree of innovation activity of coal mining enterprises, as well as the extremely low level of influence of the results of the introduction of innovations on ensuring compliance with modern technical standards and regulations - most of the innovations does not contribute to achieving compliance of production conditions with modern standards.

6. Deterioration of environmental indicators: growth of production and consumption waste associated with the activities of coal mining enterprises; decrease in the share of captured and neutralized substances released into the atmosphere.

7. Opposite dynamics of the volume of funds allocated for environmental protection, and the results obtained with this, which causes an urgent need to increase the efficiency of use of these funds. 


\section{Conclusion}

Based upon spoken above, coal mining enterprises must:

- formulate comprehensive development programs that ensure rational and safe nature management;

- carry out the gradual converting of production facilities to waste-free and resource-saving technologies, allowing to minimize emissions and discharges of harmful substances into the environment;

- focus on advanced standards in the field of industrial and environmental safety and environmental protection;

- carefully evaluate the need for investment in environmental projects with an analysis of the level of possible returns on their implementation;

- change the attitude of owners and management of companies to environmental problems by increasing their social and environmental responsibility.

\section{References}

1. G. Ditommaso, M. Gaff, F. Kacík, A. Sikora, J. Clean. Prod., 252, 119793 (2020)

2. J. Pyssa E3S Web of Conferences, 19, 02021 (2017)

3. S. Vambol, V. Vambol, Y. Suchikova, Scientific and practical problems of application of ecological safety management systems in technics and technologies (Publishing House WSZiA, Opole, 2017)

4. P. M. Costa, A. Aibeo, P. Albuquerque 18th Int. Cong. of Mech. Eng., 18, 67 (2005)

5. O. B. Sheveleva, E. V. Slesarenko, V. V. Mishchenko, A. B. Kiselev, IOP Conf. Series: Earth and Environmental Science, 315, 052060 (2019)

6. V. Čablík, M. Hlavata, I. Janakova and B. Tora IOP Conference Series: Materials Science and Engineering, 545, 012001 (2019)

7. M. Zautashvili, L. Eprikashvili, T. Kordzakhia, Res. J. Chem. Environ. Sci., 7, 23 (2019)

8. S. Burtsev, V. Efimov, T. Korchagina, E3S Web of Conferences, 21, 02017 (2017)

9. M. Soldán, H. Kobetičová Int. J. of Cur. Res., 7-12, 24119 (2015)

10. T. A. Alimbaev, Zh. S. Mazhitova, B. K. Omarova, Zh. B. Nurkina, IOP Conf. Series: Materials Science and Engineering 663, 012041 (2019)

11. Li Li, Yalin Lei, Qun Xu, Environ, Sci, Pollut Res., 24-1 (2017)

12. V. Snihur, D. Malashkevych, T. Vvedenska, Min. of Min. Depos., 10-2 (2016)

13. N. Bondarev, G. Bondareva, N. Ravochkin, V. Windemut, E3S Web of Conferences 105, 04002 (2019)

14. L. Takaishvili, A. Sokolov, E3S Web of Conferences, 77, 03001 (2019)

15. N. Pavlov, N. Petrov, E3S Web of Conferences, 77, 03002 (2019) 